\title{
Macroseismic intensity investigation of the November 2014, $M=5.7$, Vrancea (Romania) crustal earthquake
}

\author{
Angela Petruta Constantin ${ }^{\star}$, Iren Adelina Moldovan, Andreea Craiu, \\ Mircea Radulian, Constantin Ionescu
}

National Institute for Earth Physics, Bucharest-Magurele, Romania

\author{
Article history \\ Received March 3, 2016; accepted October 2, 2016. \\ Subject classification: \\ Vrancea seismogenic zone, Crustal earthquake, Intensity, Macroseismic questionnaires, Intensity map.
}

\begin{abstract}
On November 22, 2014, at 21:14:17 local time (19:14:17 GMT) an earthquake of local magnitude $M_{L}=5.7$ occurred in the proximity of Marasesti city in Vrancea county (Romania) in the lower crust (39 km depth). It was the largest event recorded since 120 years in this area (the maximum magnitude was estimated at $M_{w} 5.9$ for an event occurred on March 1, 1894). The main shock was followed by more than 200 aftershocks detected and located by the Romanian seismic network during two months. Immediately after the main shock was recorded, the National Institute for Earth Physics (NIEP) sent macroseismic questionnaires to all affected areas, in order to define the macroseismic field of ground shaking. According to the macroseismic questionnaires survey, the intensity reached VI MSK in the epicentral area, and the seismic event was felt up to a distance of $600 \mathrm{~km}$ from the epicenter (practically in all the extraCarpathian area). Also, this intensity value was estimated at 25 localities. The earthquake caused general panic, but the building damage was minor to moderate only. According to macroseismic observations, the damage area was extended mostly to the east and north from epicenter. After the collection of the macroseismic data and the evaluation of the macroseismic effects of this earthquake, an intensity dataset has been obtained for 680 sites. The main purpose of this paper is to investigate the macroseismic effects associated to this earthquake using the MSK-64 intensity scale in order to evaluate the impact on the regional seismic hazard assessment.
\end{abstract}

\section{Introduction}

Macroseismic intensity obtained through the quantification of the earthquakes effects is an important parameter for seismological and seismic engineering research, government officials/institutions and earthquake insurance programs. This type of data is also useful for the development of the macroseismic intensity prediction equation for specific seismic zones and for the comparison and correlation between the observed intensities and peak ground accelerations and velocities.

Macroseismic effects in Romania are dominated by earthquakes generated in the Vrancea region. More than two thirds of the country's territory are affected by seismicity generated in this region. Vrancea is a complex seismic area situated at the triple junction of three tectonic plates: the East European Plate, the Intra-Alpine micro-plate and the Moesian micro-plate [Constantinescu et al. 1976, Airinei 1977, Sandulescu 1984, Knapp et al. 2005]. This area is well-known for the concentration of seismicity at intermediate depths within a welldefined lithospheric body descending into the mantle [Bokelmann and Rodler 2014, Radulian 2014]. A rate of 3-4 destructive events (magnitude above 7) per century characterizes the activity of this source as pointed out in the Romanian earthquake catalog [Oncescu et al. 1999]. The seismic activity in the overlying crust is significantly lower in terms of frequency and moment release (Mmax <6.0). This type of seismicity is developed mainly east of the Vrancea intermediate-depth source.

The major earthquakes produced in the Vrancea subcrustal source are destructive over vast areas, extending significantly beyond the country's border [i.e., Pantea and Constantin 2011, Kronrod et al. 2013, Pantea and Constantin 2013, Constantin 2015]. For this reason, the database of associated macroseismic maps is relatively rich for these earthquakes, including instrumentally recorded and historical events. This is not the case when considering the earthquakes of the Vrancea crustal domain. However, although at smaller scale, the effects of the earthquakes located in the Vrancea crust may represent an important component in the regional seismic hazard assessment [Constantin et al. 2016]. The goal of the present work is to analyze the macroseismic effects of a recent earthquake which occurred on November 22, 2014, in the Vrancea crustal range $\left(\mathrm{M}_{\mathrm{L}}=\right.$ $5.7, \mathrm{~h}=39 \mathrm{~km}$ ). It was the largest earthquake located in the Vrancea crust since the end of 19th century when an earthquake with a magnitude estimated $\mathrm{M}_{\mathrm{w}}=\sim 5.9$ 
was reported. The event of 2014 was followed by a sequence of aftershocks lasting for more than two months: more than 200 events recorded by the permanent seismological network operated by the National Institute for Earth Physics (Romania) and located in the lower crust (16 to $50 \mathrm{~km}$ depth) (see Figure 1). The largest aftershocks occurred on December 7, 2014 $\left(\mathrm{M}_{\mathrm{L}}=4.5\right)$, and January 12, $2015\left(\mathrm{M}_{\mathrm{L}}=4.2\right)$.

Soon after the earthquake occurrence, the $\mathrm{Na}$ tional Institute for Earth Physics (NIEP) organized a survey in the felt areas using macroseismic questionnaires, in order to assign macroseismic intensities according to the Medvedev-Sponheuer-Karnik Scale (MSK-64) [Medvedev et al. 1967]. In this paper, we evaluate the results of the macroseismic survey and draw conclusions on the implications for seismic hazard assessment in Romania.

\section{Geological and seismotectonic settings of the area}

The seismic sequence that occurred in 2014 in the proximity of Marasesti belongs to the seismicity characterizing the foredeep region of the South-Eastern Carpathians. This is divided into an internal folded foredeep, and an external unfolded one, with a maximum development in the South-Eastern Carpathians bending area. The crustal seismicity in the Carpathians foredeep region is clustered near the SE Carpathians bending zone, and along the major faults such as the Peceneaga-Camena Fault, separating the Moesian Platform from the North-Dobrogea-Scythian block, and the Trotus Fault separating the North-Dobrogea orogen and Scythian Platform from the East European Platform [Mucuta et al. 2006, Radulian et al. 2007].

The Carpathian foredeep includes the Focşani Basin which is characterized on the western flank by a thick sequence of shallow lacustrine sediments, dipping towards the east [Raileanu and Diaconescu 1998, Leever et al. 2006]. The Focşani Basin formed just in front of the SE Carpathian arc bend, between the Intramoesian Fault at the south and the Trotus Fault at the north (see Figure 2). This basin has a neo-tectonic activity [Matenco et al. 2003, Tărăpoancă et al. 2003] evidenced by a large number of active normal faults with a NW-SE to NNW-SSE trend that seems to be related to the two major crustal faults existing in the area [Mucuta et al. 2006]. The western limit of the basin is not so faulted. The eastern flank of the Focşani Basin is characterized by eastward floor shallowing affected also by a regional system of active normal faults [Leever et al. 2006]. The most large-scale feature of the normal fault system along the eastern Focşani flank is the Siret fault. This system is juxtaposed with the Peceneaga-Camena fault [Matenco et al. 2007]. According to Raileanu

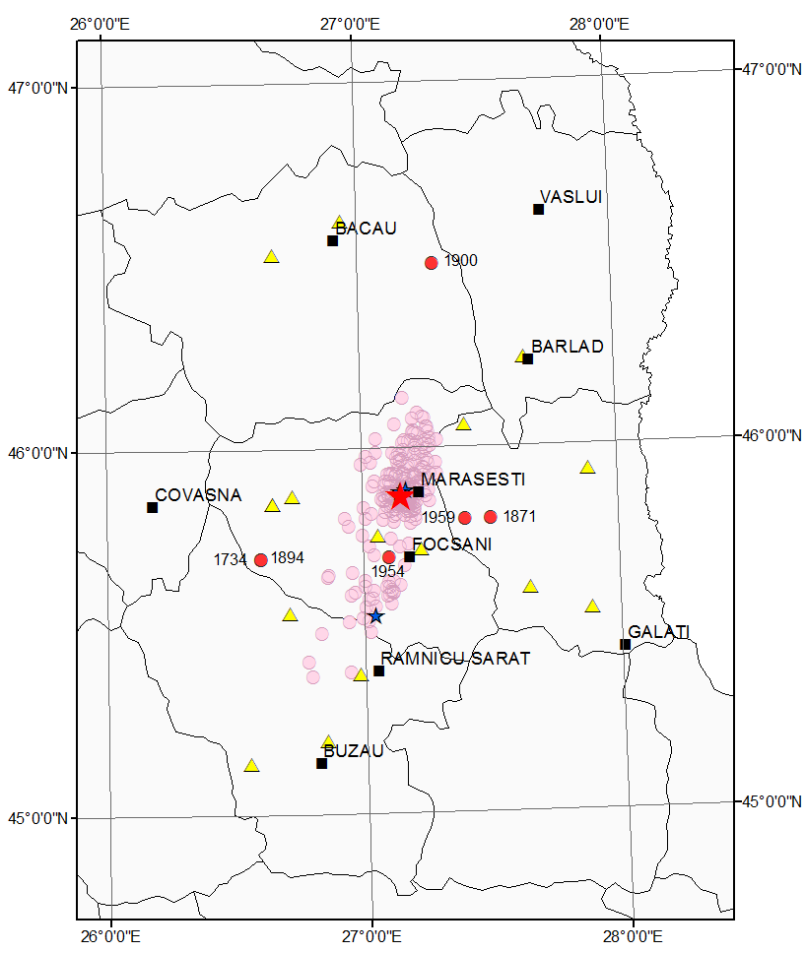

Figure 1. Mărăşeşti seismic sequence from November 22, 2014, to January 30, 2015. Red star refers to the main shock of November $22\left(\mathrm{M}_{\mathrm{L}}=5.7\right)$, the blue stars represent the aftershocks having magnitude greater than 3.0 and the pink dots are all the aftershocks of the sequence. Yellow triangles represent NIEP seismic stations (plus accelerometers sensors) installed in the area and black squares are the cities. The epicenters of crustal earthquakes with $M \geq 5$ which occurred in the Vrancea seismogenic area in historical time are also displayed in this figure with red dots.

et al. [2007] under the Focşani Basin the crust thickness reaches $46 \mathrm{~km}$, but the crystalline crust does not exceed a thickness of $25 \mathrm{~km}$, being covered by up to $15 \mathrm{~km}$ of sedimentary rocks. The crustal thickness is greater than in the surrounding foreland areas due to the major accumulation of Neogene-Quaternary sediments in the Focşani Basin [Tărăpoancă et al. 2003, Mucuta et al. 2006]. Crustal epicenters seem to focus along the Focşani Basin flanks, especially along the eastern flank, highlighting the active tectonics structures that exist at the contact between the Focşani depression and the North-Dobrogea orogen [Matenco et al. 2007, Radulian et al. 2007] (Figures 2 and 3).

Based on the historical data from the Romanian earthquake catalogue [Oncescu et al. 1999] six earthquakes with $\mathrm{M}_{\mathrm{W}}>5$ occurred in the Vrancea crustal area in the last 300 years (Figure 1). For two of them (March 1784 and March 1894) the maximum macroseismic intensity was estimated at VII on MSK scale. The 1894 crustal earthquake had maximum intensities in Panciu, Focşani and Adjud cities (all of them situated in Vrancea county). In the epicentral area, especially in Focssani, the walls of well-built buildings suffered cracks [Hepites 1893, Florinesco 1958]. 


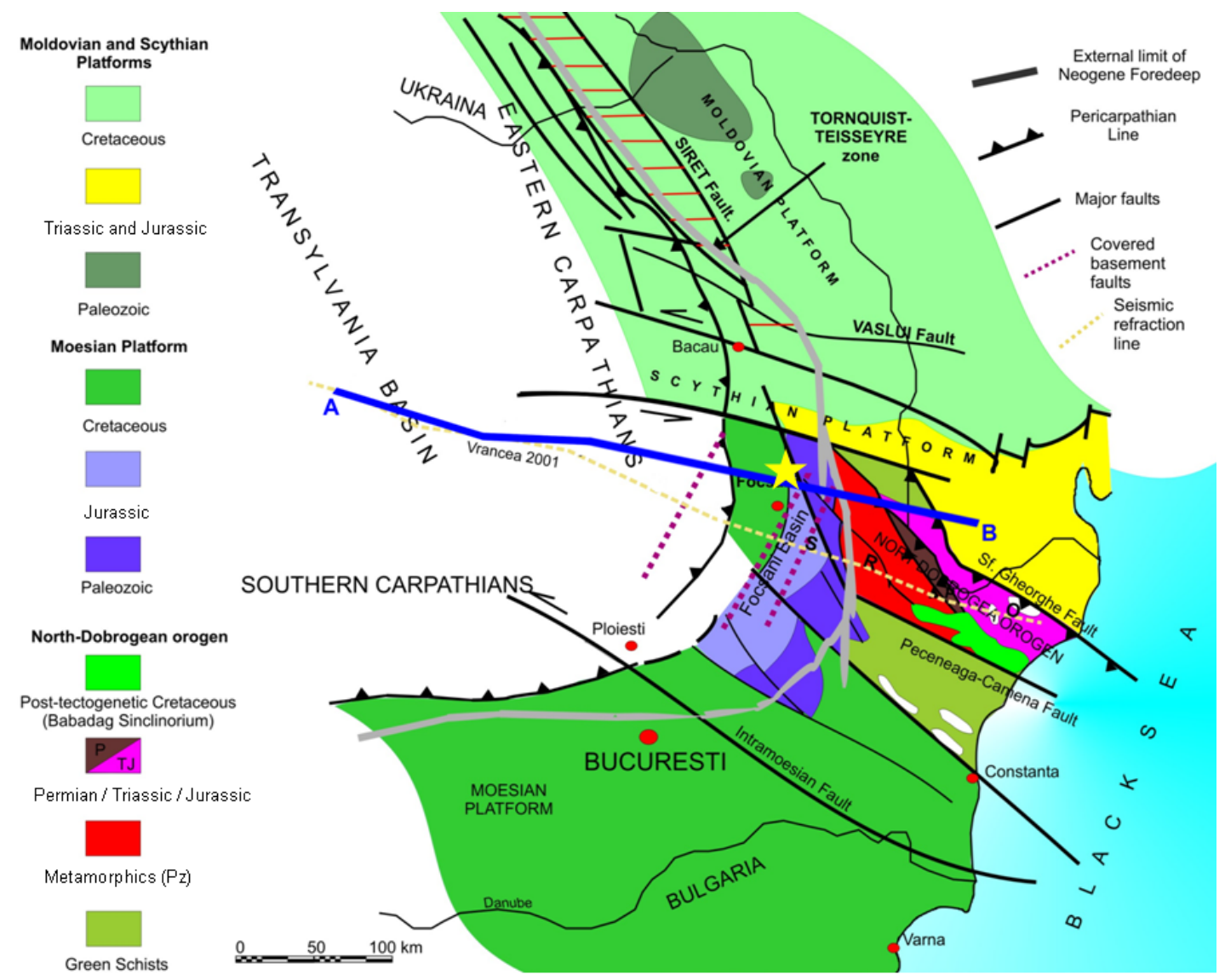

Figure 2. The main tectonic units and crustal faults in front of the SE Carpathians (modified after Badescu [2005]). The yellow star corresponds to the epicenter of the November 22, 2014, crustal earthquake. The AB line corresponds to the tectonic cross section presented in Figure 3.

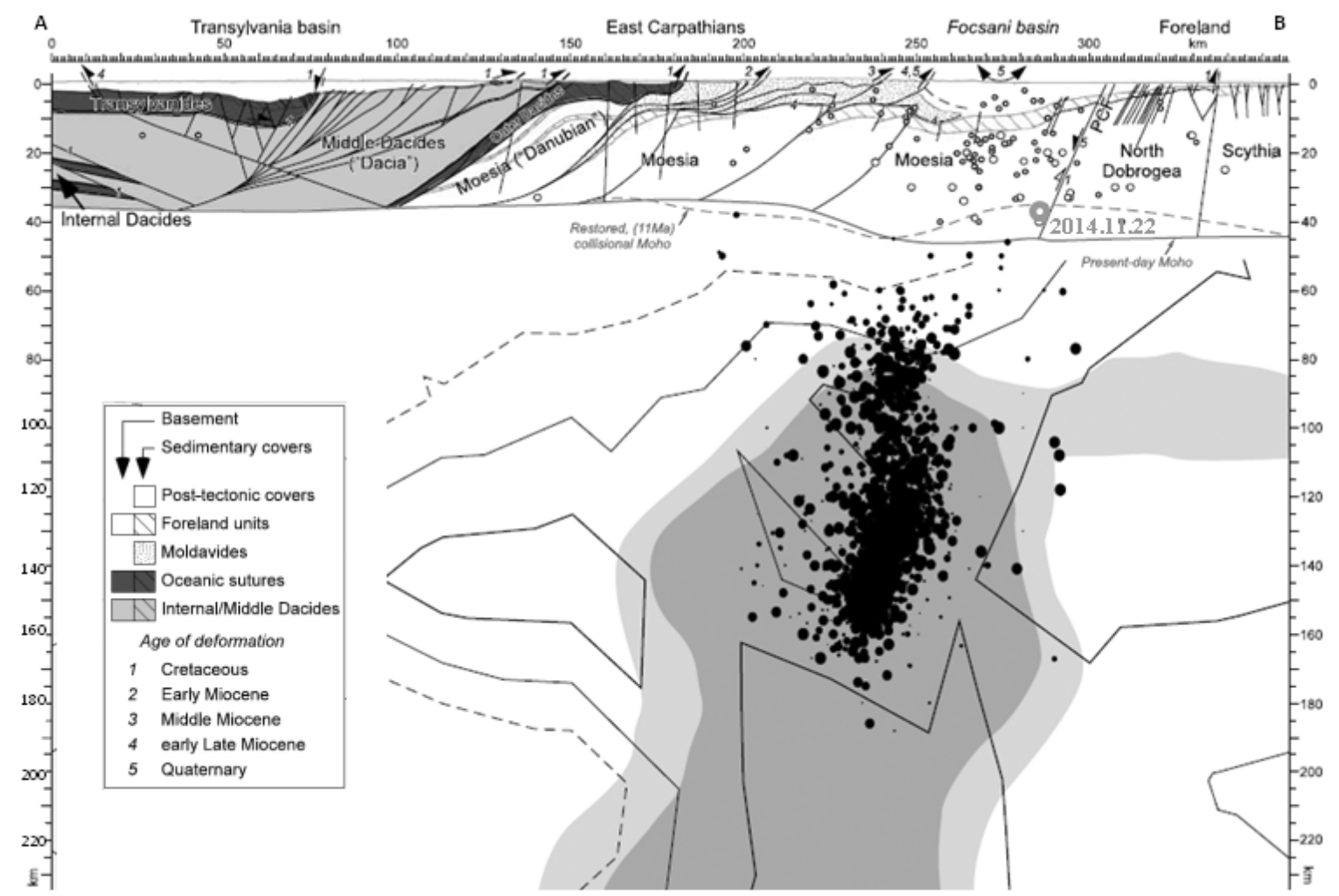

Figure 3. Tectonic cross section across the SE Carpathians (after Matenco et al. [2007]) along the line AB in Figure 2. PCF is Peceneaga-Camena Fault. Earthquakes from Vrancea zone were projected into the cross section as a function of depth and magnitude. Empty circles represent the crustal earthquakes and black dots are intermediate depth earthquakes. Green circle is the 2014 Vrancea crustal earthquake focus. 
In the last 40 years several sequences of small to moderate magnitude earthquakes were recorded in the Focşani Basin area [Popescu 2007]. They show a systematic orientation in NE-SW direction, which is parallel to the Carpathian orogen [Bala et al. 2015]. In many cases the hypocenters are located in the lower crustal domain [Tugui et al. 2009, Popescu et al. 2011]. The most recent sequence of November 22, 2014, is the best ever recorded sequence in the area ( 82 strong-motion stations installed on the Romanian territory, belonging to the NIEP strong-motion network). At the same time, the felt area was relatively wide, through the extra-Carpathian area, and as far as Ukraine, Rep. of Moldova, southern Bulgaria and south-eastern Turkey (www.emsc-csem.org).

\section{Macroseismic effects of the main shock and in- tensity map}

The macroseismic survey using questionnaires performed by the National Institute for Earth Physics (NIEP) in the felt areas and the estimation of intensities followed the recommendations on the macroseismic scale application suggested in the MSK-64 seismic intensity scale: the assessment of the intensity is based on the damage observed to the building stock and on the human perception of the effects caused by the earthquake. In other words the evaluation was done by identifying which of the descriptions for the various intensity degrees best fit all data collected for each analyzed location [e.g. Midzi et al. 2015]. It means that the correct estimation is the one that best expresses the generality of the macroseismic observations [Musson

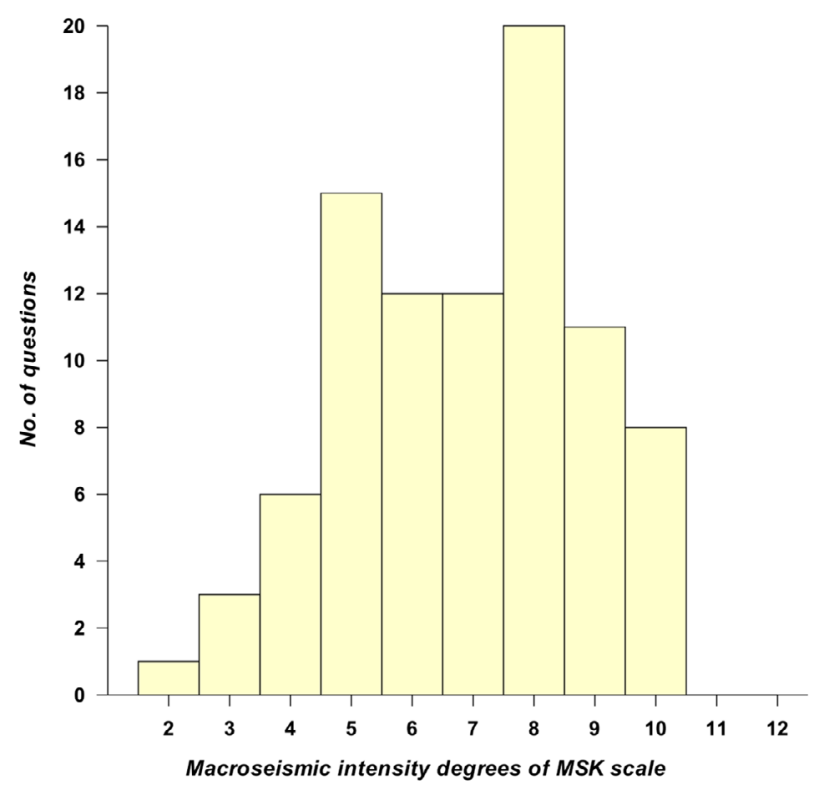

Figure 4. Number of questions related to each degree of the MSK64 seismic intensity scale, according to the macroseismic questionnaire used for the November 22, 2014, earthquake. and Cecić 2002, Cecić and Musson 2004]. For the assessment of the intensities the MSK intensity scale was used because this scale is still employed in Romania (see STAS 3684-71).

The type of macroseismic questionnaire used for this earthquake contains a number of questions related to construction types, nature and degree of damage, effects on the surroundings, and human and animal reactions. The first part of this questionnaire includes the administrative data (e.g., locality, owner, street), the typologies and vulnerability classes of buildings (i.e., A, $\mathrm{B}$, and $\mathrm{C}$ structures), and the classification of damage to buildings (all five grades) according to the MSK-64 macroseismic scale [Pantea and Constantin 2013]. Each observer thus has the possibility to select the type of building and the level of damage caused by the earthquake to the building in question. Another 54 questions are related to effects felt by the people, and the effects on objects and on the environment, and they cover the intensity degrees from II to X of the MSK-64 macroseismic scale [Pantea and Constantin 2013]. The histogram in Figure 4 shows the number of the questions related to each intensity degree according to this type of questionnaire which was used for the macroseismic study of the last four major Vrancea subcrustal earthquakes (1977, 1986 and two of 1990) [Constantin 2015]. As can be seen in Figure 4, 25 questions refer to the effects associated with the medium-low degrees of the MSK-64 macroseismic scale. Each question is directly related to a specific intensity degree, which means that every degree of the MSK-64 scale is represented in the questionnaire by various questions [Constantin and Pantea 2013].

As mentioned above, the Marasesti crustal earthquake was felt in all the extra-Carpathian area, so questionnaires were sent to all the local authorities from that area. About 30 questionnaires were sent to each locality. The filled questionnaires were sent back to NIEP by the local authorities via e-mail, fax, and mail. The average number of questionnaires received for each locality is about 20, except Bucharest with 159 forms received. Also, soon after the earthquake, people submitted reports to the National Institute for Earth Physics through dedicated online questionnaires, while others reported effects of the seismic event on social networks and various forums (or online newspapers). The online information was considered mainly as additional information to the macroseismic questionnaires. Unfortunately, the number of online questionnaires submitted by individuals who had felt the shaking was small (224 questionnaires for 35 localities). Also, analyzing the online questionnaires, we noticed that for 19 localities there were only one or two observations (questionnaires), thus reducing confidence 

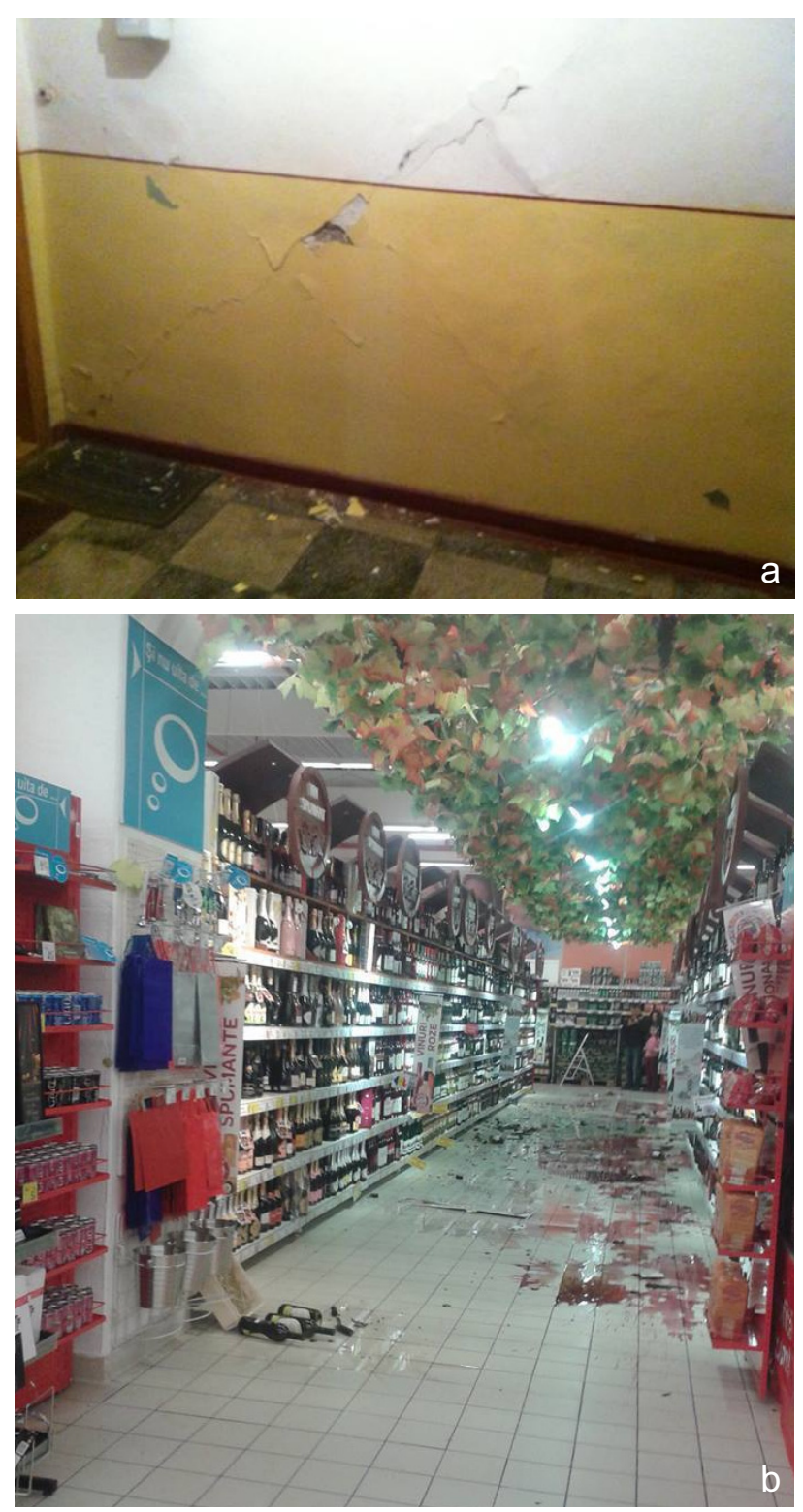

Figure 5. (a) Earthquake damage in Focşani (photo: Georgiana Loredana Carab ; Digi24); (b) Photo with bottles thrown down from supermarket shelves in Focşani (source: the Vrancea newspaper; http: / /www.ziaruldevrancea.ro).

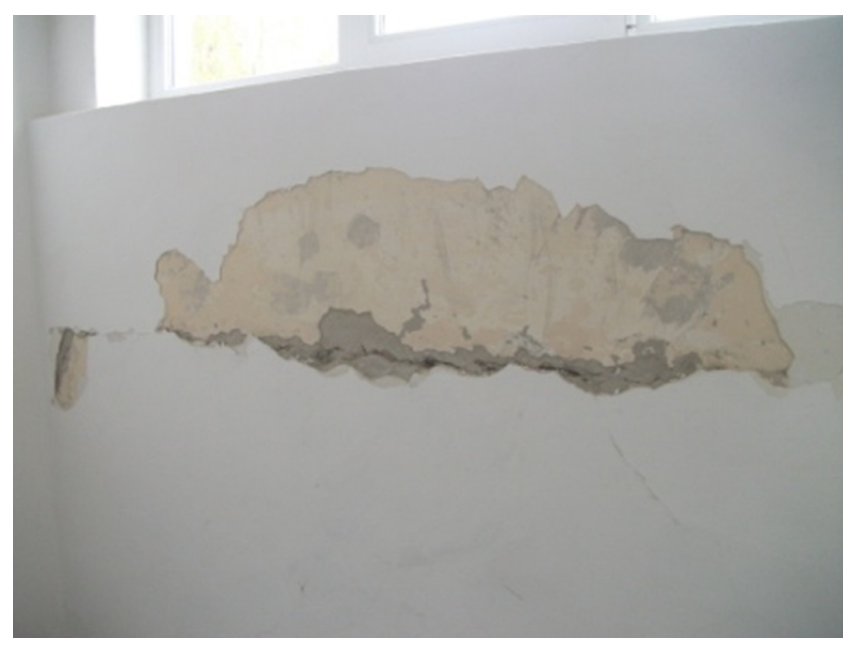

in the evaluation of the effects for those localities. The total number of localities from which positive macroseismic questionnaires forms were received was 680 . The answers to the questionnaires account for intensities between II and VI MSK degrees. For the neighboring areas (Rep. of Moldova, Bulgaria) we used the information (testimonies) provided by the European-Mediterranean Seismological Centre site (EMSC). The degree of damage was reduced in its severity, but had stronger psychological effects on people. Since the effects were not strong enough to cause important damage to the building stock, the assessment of the intensity for many sites was based only on the perception of the effects noticed or experienced by people during the earthquake [Constantin and Pantea 2013].

The most common building typologies existing in the localities where the earthquake was felt (questionnaire surveyed area) are old adobe dwellings and traditional brick houses, and also brick buildings with reinforced concrete. From the questionnaires it resulted that minor to moderate damage to buildings were reported, such as the appearance of small and sometimes open cracks in the walls, the fall of fragments of plaster in houses, and also large and extensive cracks in the walls of a few old buildings in the localities situated in the epicentral area (see Figures 5 and 6), as well as east of the epicentral area. Damages included also cracking of chimneys and ceilings.

For the November 22, 2014, Vrancea earthquake, the maximum intensity value, VI MSK, was estimated for 25 localities (Figures 7 and 8). The highest intensity values were assigned to localities where many cases of cracking and falling of fragments of plaster in the walls were observed in buildings from classes A and B (adobe and brick houses). In localities from Vrancea county some old schools and buildings were seriously affected by the earthquake (deep and open cracks in the walls,

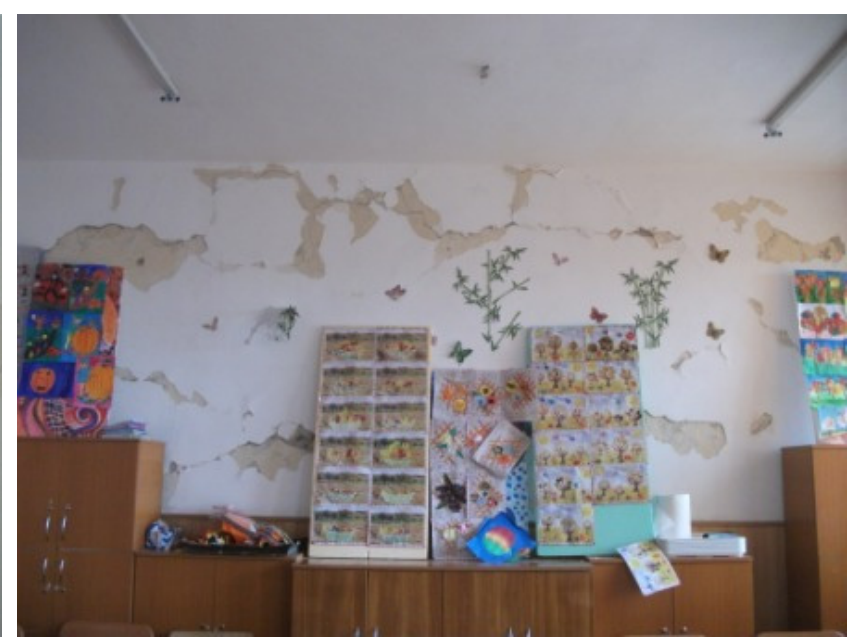

Figure 6. Cracks in the school walls in Focşani (source: the Vrancea newspaper; http://www.ziaruldevrancea.ro). 


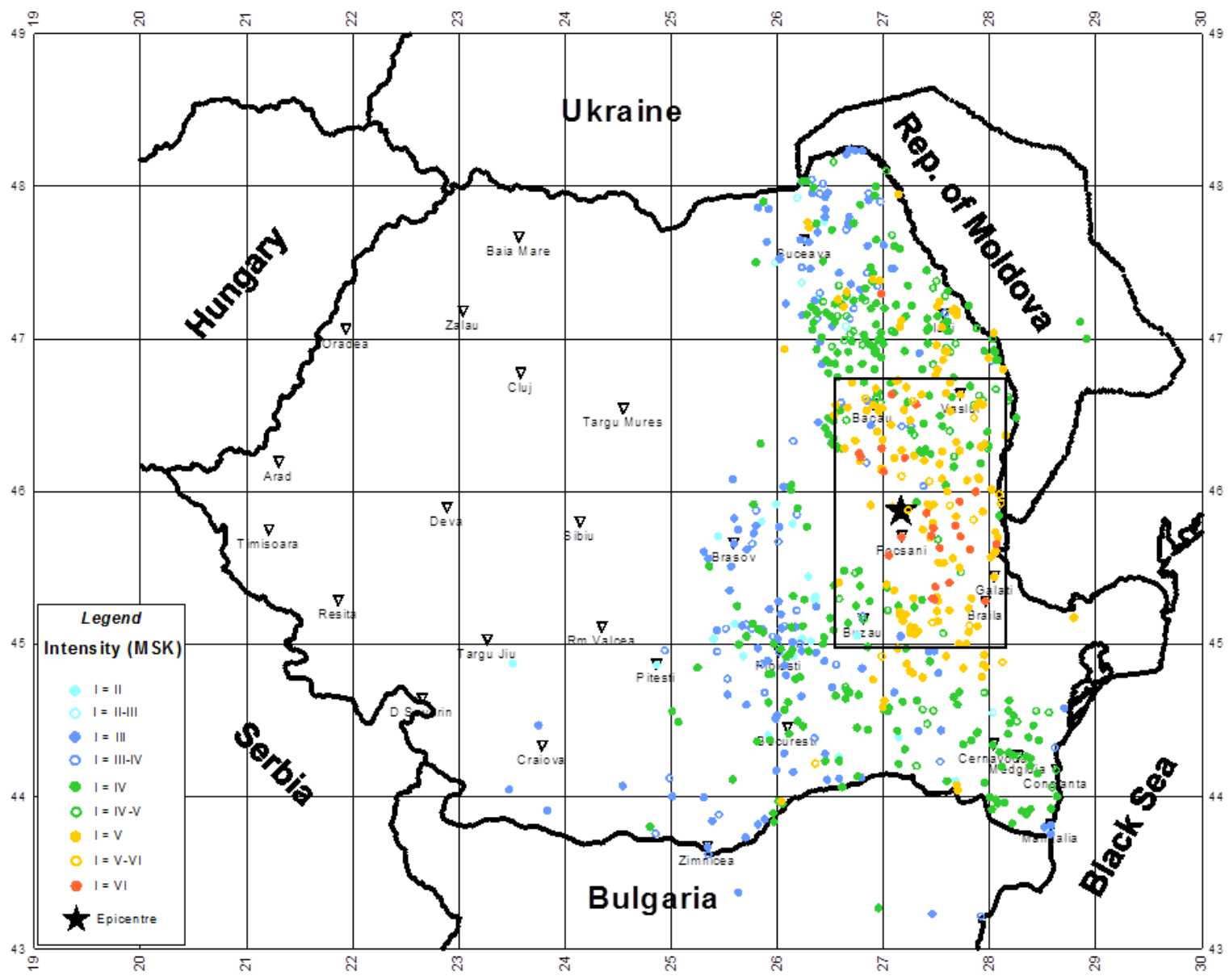

Figure 7. Macroseismic map of the main shock of November, 2014, Vrancea seismic sequence. An enlarged view of the rectangular area corresponding to the intensity distribution in the proximity of the epicenter is represented in Figure 8.

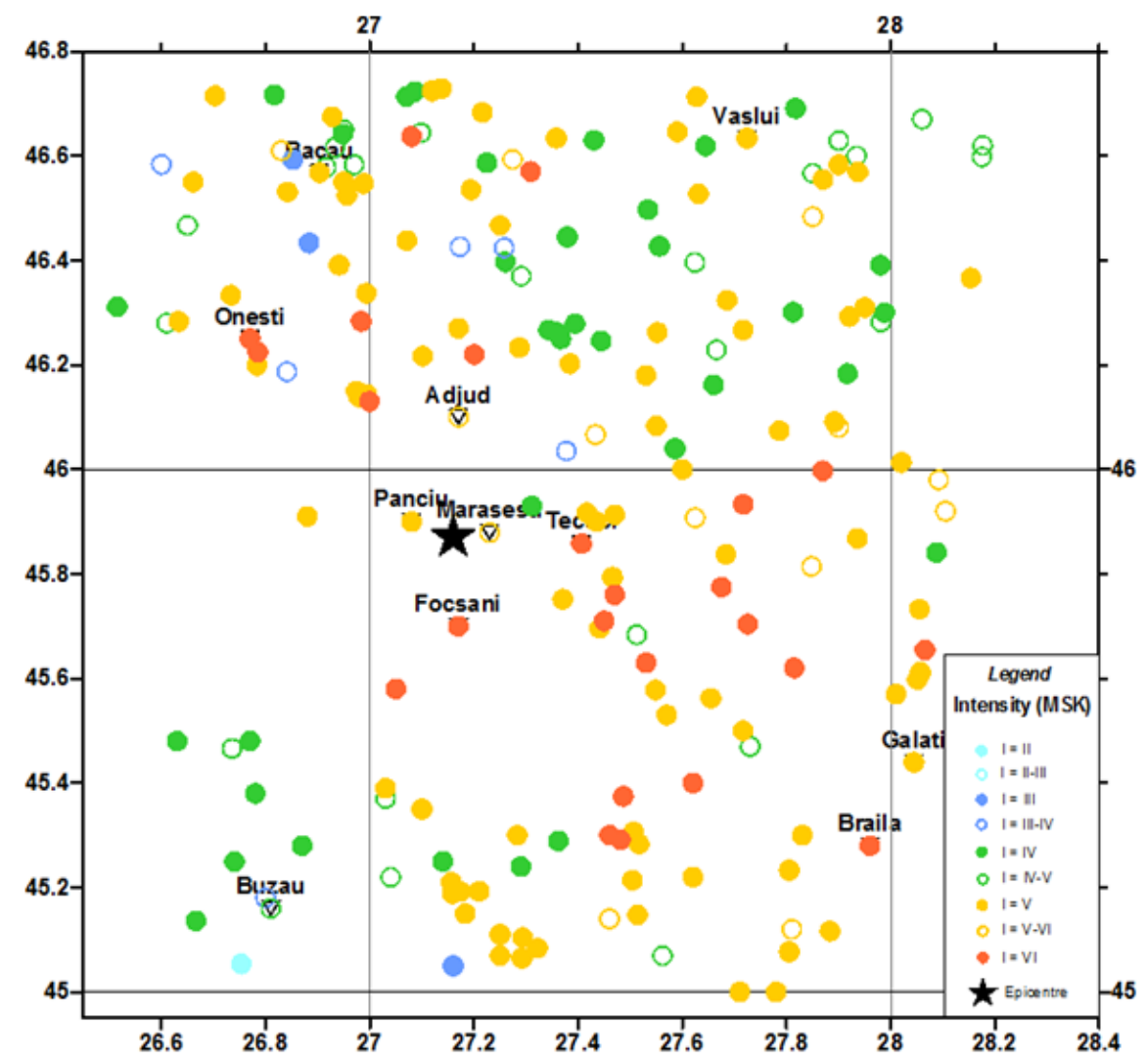

Figure 8. Intensity distribution of the November 22, 2014, Vrancea crustal earthquake in the surroundings of the epicenter. 
the fall of large fragments of plaster, see Figure 6). According to news reports (Digi24 Television channel), the masonry facade of a very old abandoned house collapsed in Tulcea. The earthquake caused power blackout in localities belonging to Vrancea and Galati counties. Also, disruption and damage to water supply systems were noticed (according to Inspectorate for Emergency Situations of Galati). Mobile phone networks were blocked during the earthquake because of the heavily increased number of telephone calls. Table 1 gives the evaluated macroseismic intensities for some of the most important cities in the felt area, and for some localities with highest intensities, together with the epicentral distances. We present below a few examples of cities and localities where maximum effects were reported and highest intensities were estimated.

For instance, in the settlement of Umbraresti (a commune in Galati county of about 6628 people), which is located $29 \mathrm{~km}$ southeast from the epicenter, the following effects were observed: small cracks in the walls and falling of fragments of plaster (damage of grade 2) of houses of type A, and in a few of type B; many people from inside were frightened and ran outdoors; in some cases objects were thrown down, including dishes and other glassware, and some of these objects were broken. Taking into account these effects, the intensity in commune of Umbraresti was estimated at VI MSK. Similar effects were observed in Onesti (Bacau), city situated at $50 \mathrm{~km} \mathrm{NNW}$ from epicenter, and in Tecuci town (Galati county) (21 km east): many people were scared and ran outside, in different buildings falling of light objects was observed, few glass objects and dishes were broken, some unfixed objects (books and others) were tilted or/and felt from shelves, and of course, minor to moderate damage to buildings was observed. In Focşani city, Vrancea county (with approx. 79,000 inhabitants) located $18 \mathrm{~km}$ south from epicenter, the same effects as in the case of sites mentioned above were reported: small cracks in the walls of buildings with vulnerability classes $A$ and $B$, the objects were thrown down and broken (dishes and other glassware), books thrown from shelves, etc. As peculiar phenomena observed in the area, loud noise accompanying the earthquake were reported.

The intensity distribution in the felt areas of Romania is somehow irregular and does not show a regular attenuation law of the intensity with the epicentral distance (see Figure 7). For instance, the localities to the south had intensities of $\mathrm{V}$ degrees, while the others felt the earthquake with intensity III or IV. Similarly, anomalous high intensities were reported for some localities in the northern part of the country. These anomalies in several localities from south and north can be explained

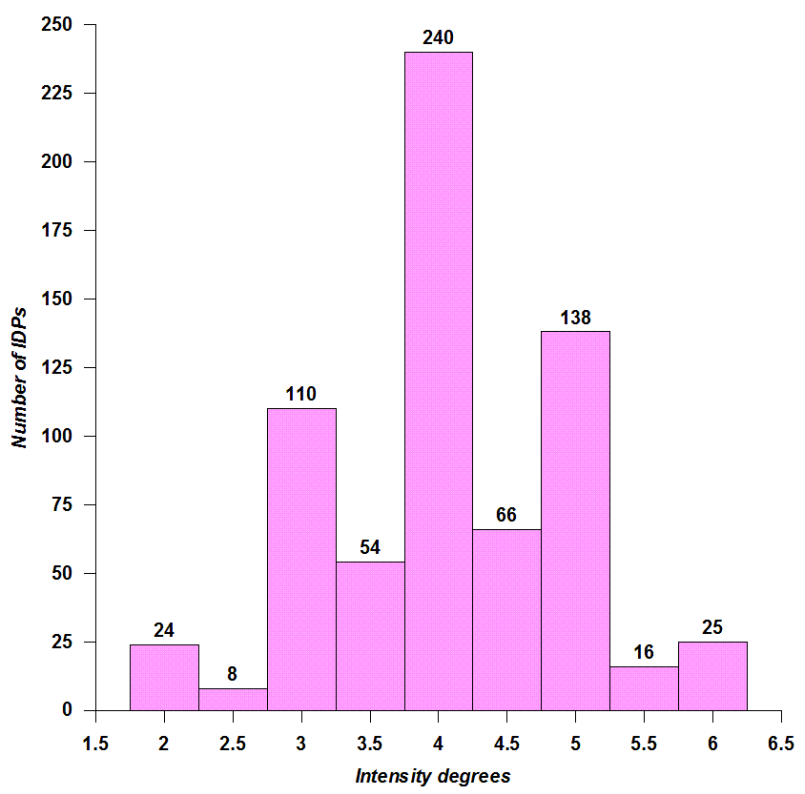

Figure 9. Number of intensity data points (IDPs) obtained for each intensity degree.

by the influence of the local soil conditions (due to some alluvial deposits in these areas) [Pantea and Constantin 2013]. Also, these high values of intensity at great distances $(>150-200 \mathrm{~km})$ could be due to a considerably long duration of the seismic waves. The distribution of intensity in degrees obtained after the evaluation of macroseismic effects is presented in Figure 9. As it can be seen in this figure, 240 intensity data points (IDPs) have an intensity value of IV MSK degrees.

\section{Conclusions}

The $\mathrm{M}_{\mathrm{L}} 5.7$ earthquake occurred on November 22, 2014, close to Mărăşeşti city was the strongest crustal earthquake that occurred in the Vrancea seismic region in the last century, both regarding magnitude and macroseismic effects. The analysis of macroseismic observations performed in this study allows us to make the following remarks:

- The macroseismic investigation of the effects produced by this earthquake was based on information data coming from 680 sites, most of them situated within the extra-Carpathian area.

- The maximum macroseismic intensity assessed after the questionnaires survey for the main shock of the seismic sequence was VI MSK. This value was estimated at 25 locations, including one in Braila, $90 \mathrm{~km}$ from the epicenter. The intensities were assigned on the basis of cumulative effects in the localities where the damages indicate these values.

- In general, in the affected area the building stock suffered minor to moderate damage; significant damages were observed only in a few old houses.

- According to macroseismic observations and 


\begin{tabular}{|c|c|c|c|c|c|c|}
\hline No. & County & City/Locality & Lat. $\mathbf{N}$ & Long. E & I (MSK) & $\Delta(\mathbf{k m})$ \\
\hline 1 & Arges & Mioveni & 44.96 & 24.94 & III-IV & 201 \\
\hline 2 & Bacau & Bacau & 46.57 & 26.90 & $\mathrm{~V}$ & 81 \\
\hline 3 & Bacau & Buhusi & 46.72 & 26.70 & $\mathrm{~V}$ & 99 \\
\hline 4 & Bacau & Moinesti & 46.48 & 26.48 & IV & 83 \\
\hline 5 & Bacau & Onesti & 46.25 & 26.77 & VI & 50 \\
\hline 6 & Bacau & Racauti & 46.22 & 26.79 & VI & 49 \\
\hline 7 & Bacau & Tg. Ocna & 46.28 & 26.61 & IV-V & 61 \\
\hline 8 & Botosani & Botosani & 47.75 & 26.67 & III & 212 \\
\hline 9 & Botosani & Dorohoi & 47.95 & 26.40 & III-IV & 238 \\
\hline 10 & Braila & Braila & 45.28 & 27.96 & VI & 90 \\
\hline 11 & Braila & Faurei & 45.11 & 27.25 & $\mathrm{~V}$ & 85 \\
\hline 12 & Braila & Ianca & 45.14 & 27.46 & V-VI & 84.5 \\
\hline 13 & Braila & Insuratei & 44.92 & 27.59 & $\mathrm{~V}$ & 111 \\
\hline 14 & Braila & Maxineni & 45.40 & 27.62 & VI & 63 \\
\hline 15 & Braila & Racovita & 45.30 & 27.46 & VI & 68 \\
\hline 16 & Brasov & Brasov & 45.66 & 25.59 & III & 124 \\
\hline 17 & Brasov & Zarnesti & 45.56 & 25.35 & III & 145 \\
\hline 18 & Bucharest & Bucharest & 44.41 & 26.11 & IV & 181 \\
\hline 19 & Buzau & Buzau & 45.16 & 26.81 & IV-V & 81 \\
\hline 20 & Buzau & Pogoanele & 44.92 & 26.98 & V-VI & 106 \\
\hline 21 & Buzau & Ramnicu Sarat & 45.39 & 27.03 & $\mathrm{~V}$ & 56 \\
\hline 22 & Calarasi & Calarasi & 44.20 & 27.31 & IV-V & 186 \\
\hline 23 & Calarasi & Oltenita & 44.06 & 26.61 & IV & 206 \\
\hline 24 & Constanta & Cernavoda & 44.34 & 28.03 & IV & 184 \\
\hline 25 & Constanta & Constanta & 44.17 & 28.63 & IV-V & 222 \\
\hline 26 & Constanta & Medgidia & 44.26 & 28.27 & IV-V & 199 \\
\hline 27 & Constanta & Techirghiol & 44.06 & 28.59 & IV-V & 231 \\
\hline 28 & Covasna & Sf. Gheorghe & 45.88 & 25.80 & III-IV & 106 \\
\hline 29 & Covasna & Tg Secuiesc & 46.01 & 26.13 & IV & 80 \\
\hline 30 & Dambovita & Moreni & 45.00 & 25.64 & IV & 153 \\
\hline 31 & Dambovita & Pucioasa & 45.09 & 25.43 & III & 160 \\
\hline 32 & Galati & Costache Negri & 45.70 & 27.73 & VI & 48 \\
\hline 33 & Galati & Cudalbi & 45.77 & 27.68 & VI & 42 \\
\hline 34 & Galati & Frumusita & 45.65 & 28.07 & VI & 75 \\
\hline 35 & Galati & Galati & 45.44 & 28.04 & $\mathrm{~V}$ & 86 \\
\hline 36 & Galati & Jorasti & 46.00 & 27.87 & VI & 57 \\
\hline 37 & Galati & Liesti & 45.63 & 27.53 & VI & 39 \\
\hline 38 & Galati & Pechea & 45.62 & 27.81 & VI & 58 \\
\hline 39 & Galati & Smulti & 45.93 & 27.72 & VI & 44 \\
\hline 40 & Galati & Tecuci & 45.86 & 27.41 & VI & 21 \\
\hline 41 & Galati & Tg. Bujor & 45.87 & 27.94 & $\mathrm{~V}$ & 60 \\
\hline 42 & Galati & Umbraresti & 45.71 & 27.45 & VI & 29 \\
\hline 43 & Giurgiu & Giurgiu & 43.89 & 25.96 & IV & 240 \\
\hline 44 & Ialomita & Slobozia & 44.57 & 27.37 & IV-V & 145 \\
\hline 45 & Ialomita & Urziceni & 44.72 & 26.64 & IV-V & 134 \\
\hline 46 & Iasi & Iasi & 47.17 & 27.58 & III-IV & 148 \\
\hline 47 & Iasi & Targu Frumos & 47.20 & 27.01 & IV & 148 \\
\hline 48 & Ilfov & Otopeni & 44.57 & 26.07 & IV & 168 \\
\hline 49 & Ilfov & Pantelimon & 44.46 & 26.24 & IV & 172 \\
\hline 50 & Neamt & Piatra Neamt & 46.93 & 26.37 & IV & 133 \\
\hline 51 & Neamt & Roman & 46.92 & 26.93 & IV & 118 \\
\hline 52 & Neamt & Tg. Neamt & 47.19 & 26.36 & IV & 159 \\
\hline 53 & Prahova & Mizil & 45.00 & 26.43 & IV & 112 \\
\hline 54 & Prahova & Ploiesti & 44.95 & 26.02 & III-IV & 136 \\
\hline 55 & Suceava & Falticeni & 47.46 & 26.31 & III & 188 \\
\hline 56 & Suceava & Suceava & 47.65 & 26.26 & III-IV & 209 \\
\hline 57 & Teleorman & Turnu Magurele & 43.76 & 24.85 & III-IV & 297 \\
\hline 58 & Vaslui & Barlad & 46.23 & 27.67 & IV-V & 56 \\
\hline 59 & Vaslui & Vaslui & 46.63 & 27.72 & $\mathrm{~V}$ & 95 \\
\hline 60 & Vrancea & Adjud & 46.10 & 27.17 & V-VI & 26 \\
\hline 61 & Vrancea & Focsani & 45.70 & 27.17 & $\mathrm{VI}$ & 18 \\
\hline 62 & Vrancea & Panciu & 45.90 & 27.08 & $\mathrm{~V}$ & 6.5 \\
\hline 63 & Vrancea & Urechesti & 45.58 & 27.05 & $\mathrm{VI}$ & 33 \\
\hline 64 & Vrancea & Marasesti & 45.88 & 27.23 & V-VI & 5.5 \\
\hline
\end{tabular}

Table 1. Seismic intensities for the important cities in the felt area, and for some localities with maximum effects. 
mapping, the damage area was extended mostly to the east and north from epicenter.

The damage suffered by building stock and especially by the old (historical) buildings observed in several localities highlights the importance of buildings consolidation and for the future, the compliance with seismic design codes and specifications.

The macroseismic study performed in the presented paper provides a valuable database of IDPs useful for the development of the seismic intensity prediction equation for the earthquakes of the Vrancea crustal domain and, also for the evaluation of the impact on the regional seismic hazard.

Acknowledgements. We want to thank to public authorities for helping us in the collection of the macroseismic information, and especially to the General Inspectorate for Emergency Situations (IGSU). We also thank the two anonymous reviewers for helpful comments and recommendations which led to the improvement of the manuscript. This paper was partially carried out within Nucleu Program, supported by ANCSI, projects no. PN 163501 06, PN 1635 0301 and PN 16350305 and the Partnership in Priority Areas Program - PNII, under MEN-UEFISCDI, DARING Project No. 69/2014.

\section{References}

Airinei, St. (1977). Earth genesis. Its evolution and internal structure (in Romanian), Ed. Stiintifica si Enciclopedica, Bucuresti.

Badescu, D. (2005). The Evolution of the TectonoStratigraphy of the Eastern Carpathians During Mesozoic and Neogene Times, Ed. Econ., Bucharest, 308 p. (in Romanian).

Bala, A., V. Raileanu, C. Dinu and M. Diaconescu (2015) Crustal seismicity and active fault systems in Romania, Rom. Rep. Phys., 67 (3), 1176-1191.

Bokelmann, G., and F.A. Rodler (2014) Nature of the Vrancea seismic zone (EasternCarpathians) - New constraints from dispersion of first-arriving P-waves, Earth Planet. Sc. Lett., 390, 59-68.

Cecić, I., and R.M.W. Musson (2004) Macroseismic surveys in theory and practice, Nat. Hazards, 31, 39-61.

Constantin, A.P., and A. Pantea (2013). Macroseismic field of the October 27, 2004 Vrancea (Romania) moderate subcrustal earthquake, J. Seismol, 17 (4), 1149-1156; doi:10.1007/s10950-013-9383-2.

Constantin, A.P. (2015). Studies and researches in the field of Macroseismology with application for earthquakes occurred on the Romanian territory (in Romanian), Ed. Granada, 978-606-8254-57-9, 212 p.

Constantin, A.P., R. Partheniu and I.A. Moldovan (2016). Macroseismic intensity distribution of some recent Romanian earthquakes, Rom. Journ. Phys., 61 (5/6), 1120-1132.

Constantinescu, L., P. Constantinescu, I. Cornea and V. Lăzărescu (1976). Recent seismic information on the lithosphere of Romania, Rev. Roum. Géol., Géophys. et Géogr., Géophysique, 20, 33-40.

EMSC (2014). European Mediterranean Seismological Centre; http:/ / www.emsc-csem.org.

Florinesco, A. (1958). Catalogue of Earthquakes felt in the Territory of the People's Republic of Romania (Catalogue des Tremblements de Terre Ressentis sur le Territoire de la RPR), Academia. Com. Nat. Geod. Geophys., Bucharest, 167 p.

Hepites, St. (1893). Registrul cutremurelor de pamant din Romania, Analele Institutului Meteorologic al Romaniei, Tom IX, Part. II, Anul 1893.

Knapp, J.H., C.C. Knapp, V. Raileanu, L. Matenco, V. Mocanu and C. Dinu (2005). Crustal constraints on the origin of mantle seismicity in the Vrancea Zone, Romania: the case for active continental lithospheric delamination, Tectonophysics, 410, 311-323.

Kronrod, T., M. Radulian, G. Panza, M. Popa, I. Paskaleva, S. Radovanovich, K. Gribovszki, I. Sandu and L. Pekevski (2013). Integrated transnational macroseismic data set for the strongest earthquakes of Vrancea (Romania), Tectonophysics, 590, 1-23; doi:10.1016/j.tecto.2013.01.019.

Leever, K.A., L. Matenco, G. Bertotti, S. Cloetingh and G.G. Drijkoningen (2006). Late orogenic verticalmovements in the Carpathian Bend Zone - seismic constraints on the transition zone from orogen to foredeep, Basin Res., 18, 521-545; doi:10.1111/j.13652117.2006.00306.x.

Matenco, L., G. Bertotti, S. Cloething and C. Dinu (2003). Subsidence analysis and tectonic evolution of the external Carpathian-Moesian Platform region during Neogene times, Sediment. Geol., 156 (1-4), 71-94.

Matenco, L., G. Bertotti, K. Leever, S. Cloetingh, S.M. Schmid, M. Tărăpoancă and C. Dinu (2007). Largescale deformation in a locked collisional boundary: Interplay between subsidence and uplift, intraplate stress, and inherited lithospheric structure in the late stage of the SE Carpathians evolution, Tectonics, 26; doi:10.1029/2006TC001951.

Medvedev, S.V., W. Sponheuer and V. Karnik (1967). Seismic intensity scale version MSK 1964, Publ. Inst. Geodynamik, 48, Jena.

Midzi, V., B. Zulu, B. Manzunzu, T. Mulabisana, T. Pule, S. Myendeki and W. Gubela (2015). Macroseismic survey of the $M_{L} 5.5,2014$ Orkney earthquake, J. Seismol, 19, 741-751; doi:10.1007/s10950015-9491-2.

Mucuta, D.M., C.C. Knapp and J.H. Knapp (2006). Constraints from Moho geometry and crustal thickness on the geodynamic origin of the Vrancea Seismogenic Zone (Romania), Tectonophysics, 420, 23-36; 
doi:10.1016/j.tecto.2006.01.018.

Musson, R.M.W., and I. Cecić (2002) Macroseismology, In: W.H.K. Lee, H. Kanamori, P.C. Jennings and C. Kisslinger (eds.), International Handbook of Earthquake and Engineering Seismology (Part A), Academic Press, 807-822; ISBN 10: 0-12-440652-1.

Oncescu, M.C., V.I. Marza, M. Rizescu and M. Popa (1999). The Romanian earthquake catalogue between 984-1997, In: F. Wenzel, D. Lungu (eds.) and O. Novak (coed.), Vrancea Earthquakes: Tectonics, Hazard and Risk Mitigation, Kluwer Academic Publishers, Dordrecht, Netherlands, 43-47.

Pantea, A., and A.P. Constantin (2011) Reevaluated macroseismic map of Vrancea (Romania) earthquake occurred on November 10, 1940, Rom. Journ. Phys., 56 (3/4), 578-589.

Pantea, A., and A.P. Constantin (2013). Re-evaluation of the macroseismic effects produced by the March 4, 1977 strong Vrancea earthquake in Romanian territory, Annals of Geophysics, 56 (1), 37-49, R0104; doi:10.4401/ag-5641.

Popescu, E. (2007). Complex study of the earthquake sequences on the Romanian territory, in Romanian, PhD Thesis, Ed. Granada, Bucharest.

Popescu, E., C. Neagoe, M. Rogozea, I.A. Moldovan, F. Borleanu and M. Radulian (2011). Source parameters for the earthquake sequence occurred in the Ramnicu Sarat area (Romania) in November - December 2007, Rom. Journ. Phys., 56 (1/2), 265-278.

Radulian, M., K.-P. Bonjer, M. Popa and E. Popescu (2007). Seismicity patterns in SE Carpathians at crustal and subcrustal domains: tectonic and geodynamic implications, Proc. of The International Symposium on Strong Vrancea Earthquakes and Risk Mitigation, October 4-6, 2007, Bucharest, Romania.

Radulian, M. (2014). Mechanisms of earthquakes in Vrancea, In: Encyclopedia of Earthquake Engineering, Springer-Verlag, Berlin, Heidelberg, 1-9; doi:10. 1007/978-3-642-36197-5_302-1, Online ISBN: 978-3642-36197-5.

Raileanu, V., and C.C. Diaconescu (1998). Some seismic signatures in the Romanian lithosphere, Tectonophysics, 288 (1/4), 127-136.

Raileanu, V., F. Hauser, A. Bala, W. Fielitz, C. Prodehl, C. Dinu and M. Landes (2007). Deep seismic sounding across the Vrancea region, Proc. of The International Symposium on Strong Vrancea Earthquakes and Risk Mitigation, October 4-6, 2007, Bucharest, Romania, 80-85.

Sandulescu, M. (1984). Geotectonica Romaniei (Geotectonics of Romania), Ed. Tehnica, Bucharest, 450 p. (in Romanian).

STAS 3684-71. Seismic intensity scale. Romanian Insti- tute for Standardization, IRS, Bucharest (in Romanian).

Tărăpoancă, M., G. Bertotti, L. Matenco, C. Dinu and S.A.P.L. Cloetingh (2003). Architecture of the Focşani Depression: a $13 \mathrm{~km}$ deep basin in the Carpathians bend zone (Romania), Tectonics, 22 (6), 1074; doi:10.1029/2002TC001486.

Tugui, A., M. Craiu, M. Rogozea, M. Popa and M. Radulian (2009). Seismotectonics of Vrancea (Romania) zone: the case of crustal seismicity in the foredeep area, Rom. Rep. Phys., 61 (2), 325-334.

\footnotetext{
${ }^{\star}$ Corresponding author: Angela Petruta Constantin, National Institute for Earth Physics, Bucharest-Magurele, Romania; email: angela@infp.ro.

(C) 2016 by the Istituto Nazionale di Geofisica e Vulcanologia. All rights reserved.
} 